Role of agricultural engineering in environmental and sustainable development

for the valley and delta areas: $1381-1399$

\title{
STUDY OF AIR POLLUTANTS, PART (1): AMMONIA AND DUST EMISSIONS PATTERNS INSIDE POULTRY HOUSES
}

\section{G. M. Abdel-Rahman ${ }^{1}$, K. M. Abdelbary ${ }^{2}$ and I. H. Al-Homidan ${ }^{3}$}

\section{ABSTRACT}

The poultry production sector in most Arabian countries has a great development due to economic trends and policy shifts occurring during the last years. Hence, there is an urgent need to quantify ammonia $\mathrm{NH}_{3}$ and dust inside poultry houses to obtain a real vision of ammonia emission both inside and outside poultry houses. The present research work aims to assess and study the pattern of emission of both ammonia and dust inside poultry houses. The familiar smell of ammonia $\left(\mathrm{NH}_{3}\right)$ can be noticed from poultry houses. Also, many parts of the poultry farms produce ammonia either when they are not well managed or when the workers agitate the litter. Results of calculations have been compared with measurement and analysis of ammonia generated and emitted from a variety of holds of poultry in a previous study, where the results showed that the concentration and the rate of emission of ammonia varies with each location, size and type of house poultry, the internal temperature, air relative humidity, air velocity, time of day and age of birds. The results also indicated that the ammonia volatilization rate depends primarily on the surface of emission- emission-surface temperature - the difference in the concentration of ammonia emission between the surface and the surrounding air. This requires detecting its presence and a measure to indicate different levels of ammonia inside the house.

Keywords: Ammonia, Dust, Emission, Environment, Ventilation Rate, Model, Poultry Houses.

\footnotetext{
${ }^{1}$ Assoc. Prof., Agric. Eng. Dept., Fac. of Agric., Cairo Univ., Giza, Egypt. Currently loaned to the Fac. Of Meteorology, Environment and Arid Land Agriculture. KAU, Jeddah, KSA.

2 Assist. Prof., Agric. Eng. Dept., Fac. of Agric., Cairo Univ., Giza, Egypt.

${ }^{3}$ Prof. of Animal Production, Fac. Of Agric. \& Vet. Med., AL-Qassim Univ., Qassim, KSA.
} 


\section{INTRODUCTION}

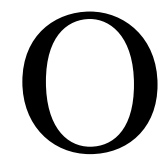
dor from poultry houses is made by a complex mixture of gases, vapors and dust. Often, this odorous mixture results as poultry manure decompose anaerobically. The familiar smell of ammonia $\left(\mathrm{NH}_{3}\right)$ and the "rotten egg" odor of hydrogen sulfide gas $\left(\mathrm{H}_{2} \mathrm{~S}\right)$ can both result from anaerobic decomposition. The anaerobic process also releases volatile fatty acids, whose odor is often found more offensive than either ammonia or hydrogen sulfide. Odorous mixtures vary with location, the size and type of poultry housing and operation, production practices, season, temperature, humidity, time of day, and wind speed and its direction. Odor control is a challenging issue for both poultry producers and researchers due to the complexity of the odor components (Abdelbary et al., 2004). Curtis (1983) reported that the airborne substances could be in the form of solid dust particles or liquid droplets. Wynne (1995) reported that in poorly ventilated animal buildings, workers might be exposed to harmful levels of gases, dust and airborne infectious agents. Xin et al. (1996) stated that increased ventilation rates resulted in excessive dust particulates and ammonia concentrations in exterior air.

Hinz and Linke (1998a) indicated that airborne gaseous and particulate pollutants from livestock feed and manure influence air quality in and around livestock buildings. Whereas air quality inside the building affects human and animal health and welfare. Emissions from the building can lead to local, meso-scale and even global environmental pollution (Hinz and Linke, 1998b; and Phillips et al., 1998). Typically, odors from animal buildings can originate from one or more of the following sources: buildings and animal holding facilities, manure storage and treatment facility, land application of manure and carcass disposal. Gaseous emissions, mainly ammonia, can be very dangerous to animals when present in high enough concentrations. The worst-case scenario for the animals is death, but other effects include decreased food intake and subsequent weight loss resulting in increased vulnerability to illness. The negative effects of gaseous ammonia on animals have been well documented for poultry at previous studies (Wynne, 1995). 
The factors affecting ammonia emission include: (a) indoor air temperature, (b) indoor relative humidity, (c) moisture content of litter, (d) $\mathrm{pH}$, (e) ventilation system, (e) keeping system and stock density (f) nutrition and animal age (h) season of year and time of day (i) waste characteristics and management (Aarnink et al., 1997; Ibrahim, 1998 and Abdelbary et al., 2004). In order to reduce ammonia emission inside commercial poultry houses, some possible techniques have been considered, Verdoes et al. (1996). These include flushing, aeration, acidification, quick removal of urine and feces, using: covering and bedding materials, chemical amendments, feed/drinking water additives, and different floor types.

Ammonia is an irritant and is also associated with soil-acidification processes (Bartali and Wheaton, 1999); the largest contributor to the human health risk parameter is ammonia from the biogas fugitive emissions (Bailey, et al., 2010). Human responses to ammonia include eye and respiratory tract irritation, and eventually asphyxia in concentrations at or above 5\%. Sneezing, salivation, and loss of appetite are caused in animals in a concentration of $0.02 \%$, and a prolonged exposure may cause excessive tearing, shallow breathing, discharge of nasal mucus, and increase respiratory diseases and pneumonia, Xue and Chen (1999). Reduced growth rate, poor feed conversion, decreased egg output and increased condemnation could result when poultry flocks which were continually exposed to ammonia levels as low as $25 \mathrm{ppm}$, Rose and Davis (1989). Laying hens exposed to aerial ammonia at 100 ppm progressively reduced egg production, Curtis (1983). To minimize these adverse effects on bird performance and health, broiler producers have been advised to keep their houses ammonia level under $25 \mathrm{ppm}$ (Xin et al., 1996, and Carr et al., 1990), so that in many countries, the threshold limit is $25 \mathrm{ppm}$ (time weighted) for an $8 \mathrm{~h}$ working day for staff and for the living environment for livestock.

Ventilation system design characteristics that may affect ammonia levels in a building include: the location of air inlets and outlets, the total ventilation rate, obstructions to airflow and temperature profiles within the space, Buiter and Hoff (1998). They stated that not only air inlet system affects the distribution and levels of ammonia in a confinement 
building but also air exhaust system. Industrial ventilation practices recommend the placement of the air exhaust near the source of the contaminant whereas the objects of concern should be located between the air inlet and the contaminant source. Xin et al. (1996) noted that the easiest and the most popular method which poultry producers used to control aerial ammonia emission at their houses was control of the ventilation rate. However, reduced ventilation rates were used to minimize energy consumption but increased ammonia concentrations which added another stress to the birds that accentuated the disease problem. Increased ventilation rates generally diluted the aerial ammonia concentration and kept the litter dry thus reducing ammonia release (Carr et al., 1990 and Xin et al., 1996).

Carr et al. (1990) stated that ammonia concentration in broiler houses has increased in the past few years due to two factors: (a) the high cost of energy caused producers to reduce air leakage in broiler houses and to use limited area brooding that reduced energy consumption up to one-half and (b) ventilation rates were reduced to conserve as much heat as possible in the winter months and to reduce the electricity required to power ventilation fans. Xin et al. (1996) stated that increased ventilation escalated building heat loss that would result in more fuel use and requirement of large heating capacity. It, also, resulted in excessive dust particulates and ammonia concentrations in exterior air. Zhang et al. (1994) reported that ammonia released from pits is increased with increases in air velocity over the manure surface.

Hellickson and Walker (1983) mentioned that the ammonia concentration in a poultry facility was quite variable. In a ventilated turkey building, the average concentration was $50 \mathrm{ppm}$ but did get as high as $110 \mathrm{ppm}$. In one broiler building maintained at temperature of $24{ }^{\circ} \mathrm{C}$ and a ventilation rate of $1.1 \mathrm{~m}^{3} / \mathrm{h}$ per bird, the average concentration varied from 15 to $90 \mathrm{ppm}$. Doubling the ventilation rate to $2.3 \mathrm{~m}^{3} / \mathrm{h}$ per bird reduced the concentration to a maximum of $50 \mathrm{ppm}$. Alchalabi et al. (1996) reported that lower winter ventilation rates, which are commonly used to control moisture, helped maintain higher inside temperature which lowered feed consumption and improved revenue margins for cooler days. He, also, stated that ammonia concentrations inside poultry 
houses were well below maximum allowable concentrations $(<35 \mathrm{ppm})$ even with low ventilation rate $\left(0.2 \mathrm{~m}^{3} / \mathrm{h} /\right.$ bird). Schuld (1999) reported that increasing house ventilation, which dilutes the indoor house air, could decrease ammonia; total ammonia emission from the barn is the same for wall fan, ceiling fan or pit fan ventilation systems

Monteny et al., (1996) stated that measurements of the ammonia emission from naturally ventilated houses were technically complex, expensive and labor intensive, mainly due to difficulties in the determination of the ventilation rate. Wheeler et al. (1999) and Yang et al. (2000) reported that measuring ammonia emission from poultry manure stored in confined facilities was difficult. However, several researchers have reported that the presence and concentration of several principle manure odor components were indicative of total odor quantity or quality (Zhang et al., 1997; and Dugba et al., 1999). Hobbs et al., (1999) did not find any correlation between the emission rates of odor expressed as odor concentration and any odorant, but they found a significant correlation between individual odorants and gases.

According to Monteny (2001), ammonia volatilization form poultry excreta can be described as two step processes. In the first step, urea is produced from the microbiological decomposition of uric acid. In the second step, the urea is further converted to $\mathrm{NH}_{3}$ by the enzyme urease:

$$
\mathrm{CO}\left(\mathrm{NH}_{2}\right)_{2}+\mathrm{H}_{2} \mathrm{O} \stackrel{\text { urease }}{\longrightarrow} 2 \mathrm{NH}_{3}+\mathrm{CO}_{2}
$$

The first step is relatively slow (within days) compared to urea decomposition (within hours). Following the urea decomposition $\mathrm{NH}_{3}$ becomes in equilibrium with ionized ammonium. This aquatic equilibrium is temperature $(\mathrm{T})$ and $\mathrm{pH}$ dependent:

$$
\mathrm{NH}_{3}+\mathrm{H}_{2} \mathrm{O} \stackrel{\mathrm{pH}, \mathrm{T}}{\longleftrightarrow} \mathrm{NH}_{4}+\mathrm{OH}^{-}
$$

The unionized $\mathrm{NH}_{3}$ in the aquatic (l) environment (e.g. slurry or urine pools above floors) is in equilibrium with gaseous (g) $\mathrm{NH}_{3}$ at the liquid/air boundary according to the temperature ( $\mathrm{T}$ ) dependent Henry's law of distribution:

$\mathrm{NH}_{3}(\mathrm{l}) \stackrel{\mathrm{T}}{\longleftrightarrow} \mathrm{NH}_{3}(\mathrm{~g})$ 
The gaseous $\mathrm{NH}_{3}$ at the boundary (bound) may volatilize to the ambient air. This volatilization process, convective mass transfer, depends on the temperature (T) and the air velocity $(\mathrm{V})$ above the liquid:

$$
\mathrm{NH}_{3} \text { (g, bound ) } \stackrel{\mathrm{T}, \mathrm{V}}{\longrightarrow} \mathrm{NH}_{3}(\mathrm{~g}, \text { air })
$$

Monteny (2001) reported that the processes described in equations (1) to (4) are particularly valid for the animal houses and during indoor and outdoor storage of excreta. However, emission levels from indoor stores greatly depend on the type of excreta, the climatic conditions (temperature, air velocity), the duration of storage and the presence of a cover on the slurry basin. The magnitude of the $\mathrm{NH}_{3}$ emission from outdoor stores depends on the application technique, the type and composition of the excreta and the actual soil and climatic conditions.

Nitrogen fixation is the process of gradually changing nitrogen $\left(\mathrm{N}_{2}\right)$ into forms that plants can use. Microorganisms such as bacteria in the soil and algae in the water, and atmospheric parameters such as lighting are responsible for the natural nitrogen fixation. Some nitrogen-fixing bacteria are free-living in the soil (non-symbiotic) whereas other exits only symbiotically with higher plants (symbiotic nitrogen fixer).

In water-quality analysis, total nitrogen includes the organic, total ammonia $\left(\mathrm{NH}_{3}+\mathrm{NH}_{4}\right)$, nitrite $\left(\mathrm{NO}_{2}\right)$ and nitrate $\left(\mathrm{NO}_{3}\right)$ forms. Total Kjeldahl nitrogen includes the total organic and total ammonia nitrogen. The ammonia, nitrite and nitrate forms of nitrogen may be expressed in terms of the concentration of $\mathrm{N}\left(\mathrm{NO}_{3}-\mathrm{N}\right.$ or $\left.\mathrm{NH}_{4}-\mathrm{N}\right)$ or in terms of the concentration of the particular ion or molecule $\left(\mathrm{NO}_{3}\right.$ or $\left.\mathrm{NH}_{4}\right)$. Previous researches reported attempts to address the ammonia emission problems by quantify the effect of several factors on ammonia emission and ammonia concentration in air.

Livestock housing is an important source of emissions of particulate matter (PM). Levels of (PM) in livestock houses are high, influenced by kind of housing and feeding, animal type, and environmental factors (Lo'pez, et al., 2010). They added also, that high concentrations of PM can threaten the environment, the health and welfare of humans and animals. PM in livestock houses is mainly coarse, primary in origin, and organic; it can adsorb and contain gases, odorous compounds, and microorganisms, which can enhance its biological effect. Improved knowledge 
on particle morphology, primarily size, composition, levels, and the factors influencing these can be useful to identify and quantify sources of PM more accurately.

Roumeliotis, et al. 2010(a,b) characterized the emission rates of size fractionated particulate matter, inorganic aerosols, acid gases, ammonia and methane measured over four flocks at a commercial broiler chicken facility. They mentioned that the mean emission rates of $\mathrm{PM}_{10}$ and $\mathrm{PM}_{2.5}$ were 5.0 and $0.78 \mathrm{~g}$. day ${ }^{-1}$. $\mathrm{AU}^{-1}$, respectively and ammonia emissions were seasonally dependent, with a mean emission rate of $66.0 \mathrm{~g}$. day ${ }^{-1}$. $\mathrm{AU}^{-1}$ in the cooler seasons and $94.5 \mathrm{~g}$. day ${ }^{-1} . \mathrm{AU}^{-1}$ during the warmer seasons. They added that the diurnal pattern in each pollutant's emission rate was relatively consistent after normalizing the hourly emissions according to each daily mean emission rate. Over the duration of a production cycle, all the measured pollutants' emissions increased proportionally to the total live mass of birds in the house, with the exception of ammonia.

\section{MATERIALS AND METHODS}

\section{Ammonia concentration and emission data calculations}

The concentration of ammonium ion in the sample solution can be determined from the calibration (ammonium-nitrogen standard curve), whereas, the concentration of aerial ammonia in the sample and ammonia emission rate can be calculated using the following simple model equations:

Aerial ammonia concentration $\left(\mu \mathrm{g} / \mathrm{m}^{3}\right)=\frac{\left(\text { Conc }_{\text {sample }} \times \text { Vol }_{\text {sample }}\right)}{\left(25 \times \text { Vol }_{\text {air }} / 1000\right)}$

Aerial ammonia concentration $(\mathrm{ppm})=$ Conc $_{\text {sample }_{\text {a }}} \times 1.36 \times \frac{\text { Vol }_{\text {sample }}}{\text { Vol }_{\text {air }}}$

Average ammonia emission rate $(g / h)=$

$\frac{\text { Aerial ammonia concentration }\left(\mu \mathrm{g} / \mathrm{m}^{3}\right) \times \text { Average ventilation rate }\left(\mathrm{m}^{3} / \mathrm{h}\right)}{\left(10^{6}\right)}$ 


\section{Where:}

Conc. $_{\text {sample }}$ is the concentration of ammonia in the absorbing solution, $\mu \mathrm{g} \mathrm{NH}_{4}^{+} / \mathrm{ml}$.

Vol. $_{\text {sample }} \quad$ is the final volume of the absorbing solution, $\mathrm{ml}$.

Vol. air $\quad$ is the volume of air sampled and sucked by a pump, L.

1.36 is the factor for conversion of $\mu \mathrm{g}$ ammonium ion $\left(\mathrm{NH}_{4}^{+}\right)$to $\mu \mathrm{l}$ ammonia.

Ammonia emission rate per unit volume $\left(\mathrm{g} \mathrm{NH} / \mathrm{m}^{3}\right.$. bird $)=$

$$
\frac{\text { Average ammonia emission rate }\left(\mathrm{gNH}_{3} / \mathrm{h}\right)}{\text { Specific ventilation rate }\left(\mathrm{m}^{3} / \mathrm{h} . \text { bird }\right)}
$$

Ammonia emission rate per animalunit $\left(g \mathrm{NH}_{3} / A U . h\right)=$

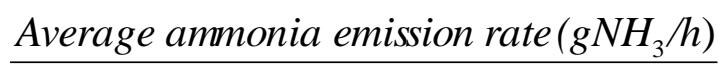

\section{$\mathrm{AU}$}

Where:

AU is the animal unit and to be equivalent to $500 \mathrm{~kg}$ live mass.

Animal unit, AU, can be calculated using the following equation:

$\mathrm{AU}$ (animal unit, dimensionless) $=$

$\underline{\text { Total number of birds } \times \text { Birds average weight }(\mathrm{kg})}$

$$
500,(\mathrm{~kg})
$$

Ammonia emission rate per unit area $\left(\mathrm{mgNH}_{3} / \mathrm{m}^{2} . h\right)=$

$$
\frac{\text { Average ammonia emission rate }\left(\mathrm{gNH}_{3} / \mathrm{h}\right)}{\left(1000 \times \text { the house floor area }\left(\mathrm{m}^{2}\right)\right)}
$$

Odor intensity (or odor strength) can be calculated using the following equations according to Misselbrook et al. (1993):

Intensity $=2.35\left(\log _{10}\right.$ Concentration $)+0.30$ 
Odor flow (the emission of the livestock building at the outlet air) can be calculated using the following equation according to Schauberger et al., (2001):

Odor flow $=\frac{\text { Concentration of odorants }}{\text { Volume }}$

\section{Aerial Ammonia Measurements.}

The colorimetric method was applied for ammonia measurement. This method uses Nessler's reagent (formula $\mathrm{HgI}_{2}$. $2 \mathrm{KI}$ ) which gives an intense color when added to solutions containing the ammonium ion, $\mathrm{NH}_{4}{ }^{+}$. The resultant ammonium ion is determined by Spectrophotometric method at $460 \mu \mathrm{m}$. Ammonium ion $\mathrm{NH}_{4}{ }^{+}$concentration values $(\mu \mathrm{g} / \mathrm{mL})$, optical density data at $460 \mu \mathrm{m}$ (absorbance, percent transmittance) are illustrated in Table (1). Also, Figure (1) illustrates the relationship between the absorbance (at $460 \mu \mathrm{m}$ ) the concentration of $\mathrm{NH}_{4}{ }^{+}$(the standard curve of ammonia). The ammonium-nitrogen measurement was performed using the Kjeltec Auto 1030 Analyzer according to the Kjeldahl method of nitrogen analysis. In essence, the ammonium ion $\left(\mathrm{NH}_{4}{ }^{+}\right)$in the solution was treated with an excess of strong base following distillation. The liberated ammonia was titrated.

In their study, Abdelbary et al.(2004) used semi-closed poultry house with dimensions of $100 \mathrm{~m}$ length X $12.32 \mathrm{~m}$ width and had 154 air inlets and 2 pad-type evaporative cooling system as inlets at the sidewall. Air inlets dimensions were $132.5 \times 102 \mathrm{~cm}$. Each house is divided in to 5 partitions in addition to a service room $(4.5 \mathrm{mx} 12.32 \mathrm{~m})$. The first partition, only, is equipped with pad-type evaporative cooling system. The length of pad inlet is 20 meters, and the length of each partition is 20 meters except the last one that is $\mathbf{1 5 . 5}$ meters in length. At the back side of the house there were 6 galvanized steel exhaust fans (1.5 HP) and had dimensions of $138 \times 138 \times 45 \mathrm{~cm}$, and propeller diameter of $124.5 \mathrm{~cm}$ and is made from the. Each fan delivered $34730 \mathrm{~m} 3 / \mathrm{h}$ as a maximum airflow rate (total fan capacity) at $30 \mathrm{~Pa}$. Also, they measured ammonia in ambient air acidimetrically, whereas, ammonia is collected by aspiration of air through dilute $\mathrm{H}_{2} \mathrm{SO}_{4}$ of known concentration in a standard impinger. 
Table (1). Ammonium Ion $\mathrm{NH}_{4}{ }^{+}$Standard Curve Data.

\begin{tabular}{ccc}
\hline \multirow{2}{*}{ Concentration $(\mu \mathrm{g} / \mathrm{ml})$} & \multicolumn{2}{c}{ Optical Density at $460 \mu \mathrm{m}$} \\
\cline { 2 - 3 } & Absorbance & Transmittance $(\%)$ \\
\hline 0 & 0.000 & 100.0 \\
2 & 0.002 & 99.7 \\
4 & 0.003 & 99.4 \\
6 & 0.004 & 99.2 \\
8 & 0.005 & 98.9 \\
10 & 0.012 & 97.2 \\
12 & 0.017 & 96.3 \\
14 & 0.035 & 92.4 \\
16 & 0.036 & 92.0 \\
18 & 0.037 & 91.8 \\
20 & 0.040 & 90.0 \\
\hline
\end{tabular}

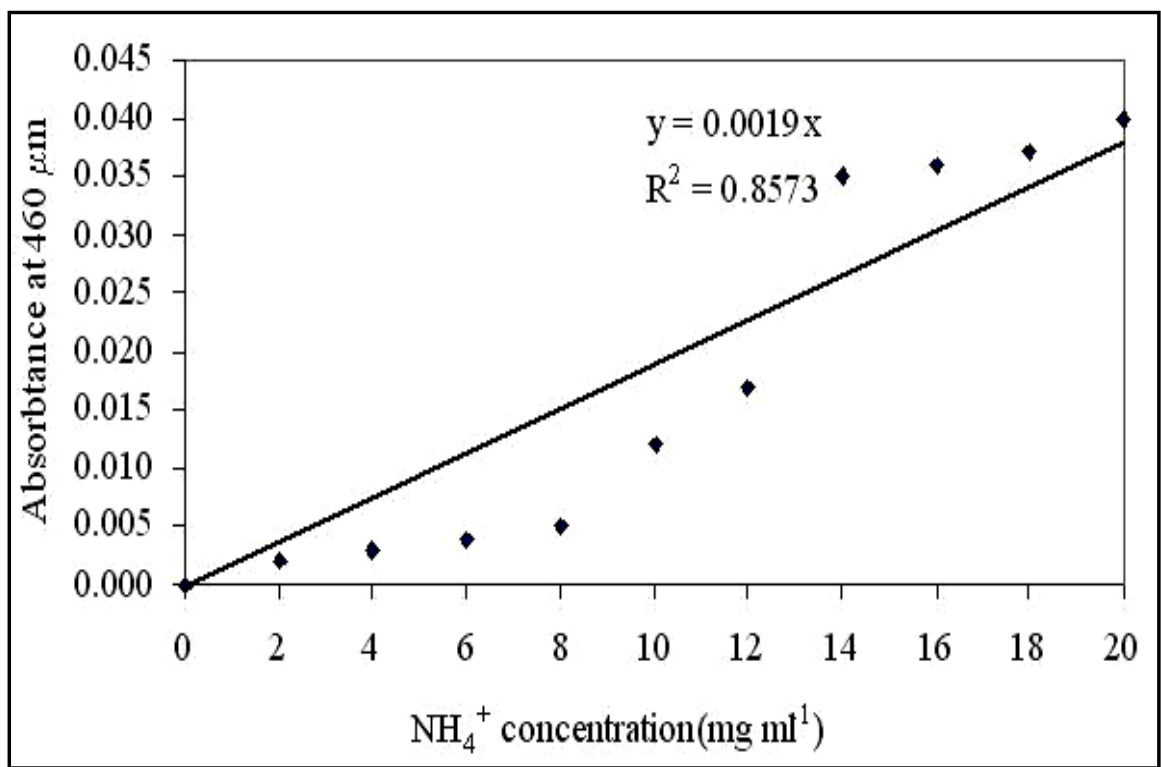

Fig. (1). Ammonium Ion $\mathrm{NH}_{4}{ }^{+}$Standard Curve.

\section{RESULTS AND DISCUSSION}

\section{Aerial ammonia emissions data.}

Aerial ammonia emission data were calculated using a proposed simple model equations using ammonia concentration measurements from previous study (Abdelbary et al., 2004). In their study, field data were measured and collected for two laying hen breeds $\left(\boldsymbol{C O B B}{ }^{T M} 500\right.$ and 
$\operatorname{ROSS}^{T M} 308$ ) at two different ages (41 and 26 weeks) and throughout four periods of continuous three days.

Aerial ammonia concentrations in $\mu \mathrm{g} / \mathrm{m}^{3}$ and different ammonia emission modes that included general ammonia emission rate, $\mathrm{g} \mathrm{NH}_{3} / \mathrm{h}$, ammonia emission rate for unit area, $\mathrm{mg} \mathrm{NH}_{3} / \mathrm{m}^{2}$.h, are shown in Fig (2). Ammonia emission rate for bird, $\mathrm{g} \mathrm{NH} / \mathrm{N}^{3}$.bird and ammonia emission rate for animal unit (or living unit), g $\mathrm{NH}_{3}$ /AU.h vs. average ammonia concentrations are illustrated in Fig. (3).

Whereas, Table (2) gives an overall idea about ammonia emission modes and its relationships with aerial ammonia concentrations, and average ventilation rates.

Table (2). Aerial ammonia emission data calculated using a proposed simple model $C O B B^{T M}$ breed (age 41 weeks) through the experimental period of continuous three days, According to Abdelbary et al., (2004).

\begin{tabular}{|c|c|c|c|c|c|c|c|}
\hline Period & $\begin{array}{l}\text { Conc., } \\
\mu \mathrm{g} / \mathrm{m}^{3}\end{array}$ & $\begin{array}{c}\text { Average } \\
\text { ventilation } \\
\text { rate, } \\
\mathrm{m}^{3} / \mathrm{h} \\
\end{array}$ & $\begin{array}{l}\text { Emission } \\
\text { rate, } \mathrm{g} / \mathrm{h}\end{array}$ & $\begin{array}{c}\text { Average } \\
\text { ventilation } \\
\text { rate, } \\
\mathrm{m}^{3} / \mathrm{h} . \text { bird } \\
\end{array}$ & $\begin{array}{c}\text { Emission } \\
\text { rate, } \mathrm{g} / \mathrm{m}^{3} \\
\text { bird }\end{array}$ & $\begin{array}{l}\text { Emission } \\
\text { rate, } \\
\text { g/AU.h }\end{array}$ & $\begin{array}{l}\text { Emission } \\
\text { rate, } \\
\mathrm{mg} / \mathrm{m}^{2} \cdot \mathrm{h}\end{array}$ \\
\hline $4 \mathrm{am}$ & 749.75 & 83352 & 62.49 & 15.21 & 4.11 & 1.51 & 52.08 \\
\hline $8 \mathrm{am}$ & 787.24 & 83352 & 65.62 & 15.21 & 4.31 & 1.58 & 54.68 \\
\hline $12 \mathrm{pm}$ & 824.73 & 83352 & 68.74 & 15.21 & 4.52 & 1.66 & 57.29 \\
\hline $4 \mathrm{pm}$ & 862.21 & 83352 & 71.87 & 15.21 & 4.72 & 1.73 & 59.89 \\
\hline $8 \mathrm{pm}$ & 1001.84 & 41676 & 41.75 & 7.61 & 5.49 & 1.01 & 34.79 \\
\hline $4 \mathrm{am}$ & 937.19 & 83352 & 78.12 & 15.21 & 5.13 & 1.88 & 65.10 \\
\hline $8 \mathrm{am}$ & 862.21 & 83352 & 71.87 & 15.21 & 4.72 & 1.73 & 59.89 \\
\hline $12 \mathrm{pm}$ & 1012.16 & 83352 & 84.37 & 15.21 & 5.55 & 2.03 & 70.30 \\
\hline $4 \mathrm{pm}$ & 1049.65 & 83352 & 87.49 & 15.21 & 5.75 & 2.11 & 72.91 \\
\hline $8 \mathrm{pm}$ & 1113.15 & 41676 & 46.39 & 7.61 & 6.10 & 1.12 & 38.66 \\
\hline $4 \mathrm{am}$ & 1087.14 & 83352 & 90.62 & 15.21 & 5.96 & 2.18 & 75.51 \\
\hline $8 \mathrm{am}$ & 1124.63 & 83352 & 93.74 & 15.21 & 6.16 & 2.26 & 78.12 \\
\hline $12 \mathrm{pm}$ & 1162.11 & 83352 & 96.86 & 15.21 & 6.37 & 2.33 & 80.72 \\
\hline $4 \mathrm{pm}$ & 1237.09 & 83352 & 103.11 & 15.21 & 6.78 & 2.49 & 85.93 \\
\hline $8 \mathrm{pm}$ & 1274.58 & 41676 & 53.12 & 7.61 & 6.98 & 1.28 & 44.27 \\
\hline
\end{tabular}


As illustrated in table (2) aerial ammonia concentrations varied between $749.75 \mu \mathrm{g} / \mathrm{m}^{3}$ at the start of measurement period to $1274.58 \mu \mathrm{g} / \mathrm{m}^{3}$ at the end of this period. These concentrations met total emission rates ranged between $62.49 \mathrm{~g} \mathrm{NH}_{3} / \mathrm{h}$ to $53.12 \mathrm{~g} \mathrm{NH}_{3} / \mathrm{h}$ as a total emission rate of ammonia for the house. The emission rate calculated for the production unit (one bird) and for the unit volume of inside air ranged between 4.11 g NH$/ 3 / \mathrm{m}^{3}$.bird to $6.98 \mathrm{~g} \mathrm{NH}_{3} / \mathrm{m}^{3}$.bird. Whereas, the emission rate for animal unit (AU) or living unit (LU) (calculated for every $500 \mathrm{~kg}$ bird living weight) ranged between $1.51 \mathrm{~g} \mathrm{NH}_{3}$ /AU.h to $1.28 \mathrm{~g} \mathrm{NH}_{3} /$ AU.h. Finally, the emission rate per unit area varied between $52.08 \mathrm{mg}$ $\mathrm{NH}_{3} / \mathrm{m}^{2}$.h to $44.27 \mathrm{mg} \mathrm{NH}_{3} / \mathrm{m}^{2}$.h.

The concentration was high and increased slowly at night periods (by reducing ventilation rates to save indoor temperature) started from $8 \mathrm{pm}$ (light turn-off period) to about 4 am (the first light or feeding period). At the first period of the next day the concentration was still high and then it reduced a little bit by going the birds to feed intake and they started their activities for this day.

Increasing in ammonia concentration was referred to the increasing of ammonia volatilization through this period, this increasing was due to mixing the litter under birds by workers, collecting the eggs that caused more and rapid movements inside the house. Mixing the litter allowed the existence of aerobic bacteria that are primarily responsible for uric acid decomposition into ammonia. Ammonia volatilization still increased to the end of the day, at night it was at its maximum value and was reduced at the beginning of next day and so on.

Average ventilation rate was about $83352 \mathrm{~m}^{3} / \mathrm{h}$ at daytime and 41676 $\mathrm{m}^{3} / \mathrm{h}$ at the night period. Average ventilation rate ranged from 15.21 $\mathrm{m}^{3} / \mathrm{h}$.bird at daytime and to about $7.61 \mathrm{~m}^{3} / \mathrm{h}$.bird at the night. Ventilation rates were much more than the reported values in previous literatures. In general, the air velocity was much changeable with the time of day and become quiet, approximately, through the night by keeping of ventilation system automatically working on its cycling. Ammonia concentration increased with increasing of inside air velocity, the opposite happened when decreasing air velocity that affected ammonia and decreased the 
emission. Increasing air velocity allowed to existence of aerobic conditions which helped aerobic microorganisms in decomposition of uric acid into ammonia. Also, increasing air velocity assisted ammonia volatilization because of ammonia being lighter than the air.

Aerial ammonia concentrations in $\mu \mathrm{g} / \mathrm{m}^{3}$ and different ammonia emission modes that included general ammonia emission rate, $\mathrm{g} \mathrm{NH}_{3} / \mathrm{h}$, ammonia emission rate for unit area, $\mathrm{mg} \mathrm{NH}_{3} / \mathrm{m}^{2} . h$, are shown in Fig (2).

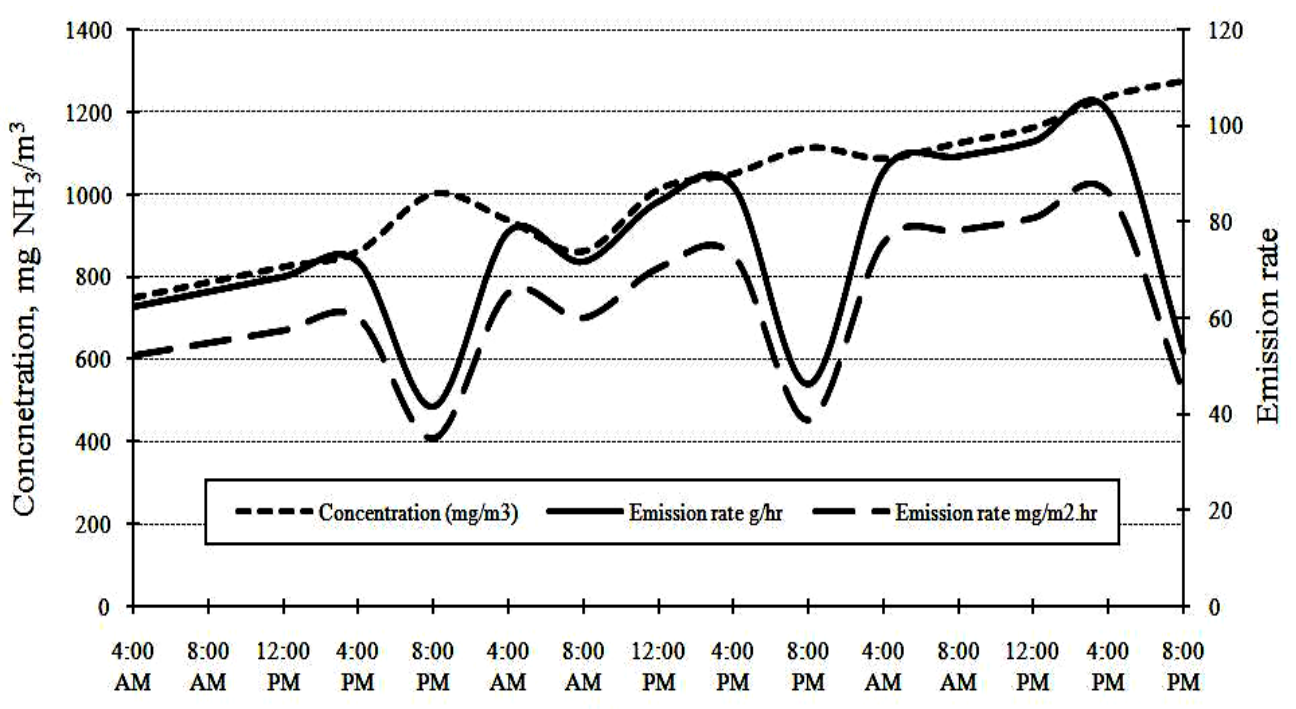

Time, hours

Fig.(2). Average ammonia concentrations vs. different emission rate modes for continuous three days.

Figure (2) shows that both of total ammonia emission rate and the emission rate for the unit of area of the house took the same trend increased with the increasing of inside temperatures and the time of experimental period. There were three reduced regions in this curve which reflected three lower values for both of total ammonia emission rate and the emission rate for the unit of area of the house, these values were $41.75,46.39$ and $53.12 \mathrm{~g} \mathrm{NH}_{3} / \mathrm{h}$ for total ammonia emission rate and $34.79,38.66$ and $44.27 \mathrm{mg} \mathrm{NH} / \mathrm{m}^{2}$.h for the emission rate for the unit of area of the house. These lower values were attributed to reducing ventilation rate to about half of its original values. This occurred at the period of light turn-off or the night period and this procedure were 
common to conserve inside temperatures at night period, so ventilation rates should be reduced through this period.

Ammonia emission rate for bird, $\mathrm{g} \mathrm{NH}_{3} / \mathrm{m}^{3}$. bird and ammonia emission rate for animal unit (or living unit), $\mathrm{g} \mathrm{NH}_{3}$ /AU.h vs. average ammonia concentrations are illustrated in Fig. (3).

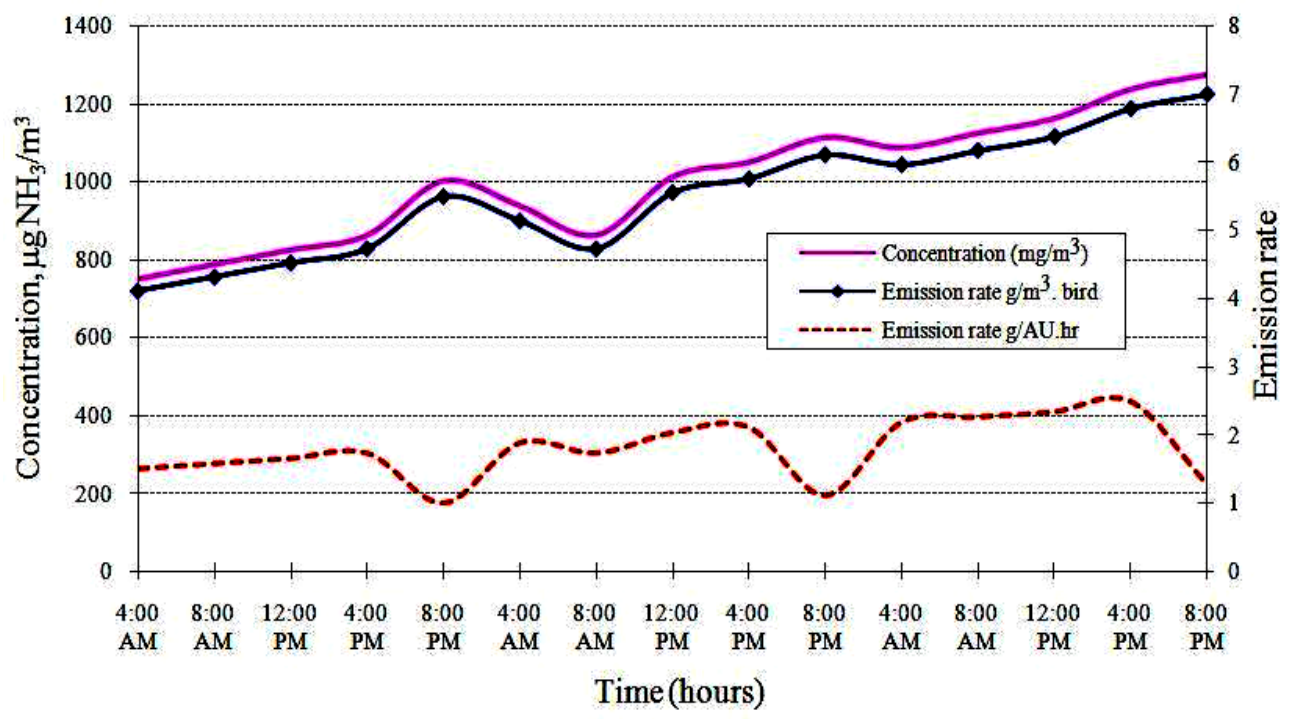

Fig. (3). Average ammonia concentrations vs. different emission rate modes for continuous three days.

Figure (3) demonstrates the relationships between inside aerial ammonia concentrations and specific values of its emission rates which were calculated for both of the production unit (one bird) and the emission rate for animal unit (AU) or living unit (LU). Similar to both previously emission modes, aerial ammonia emission pattern had the same tendency. Aerial ammonia emission rate ranged between both of $4.11 \mathrm{~g} \mathrm{NH}_{3} / \mathrm{m}^{3}$ to $6.98 \mathrm{~g} \mathrm{NH}_{3} / \mathrm{m}^{3}$ for one bird. This emission mode increased with increasing of inside temperature and because of its dependence on the concentrations of ammonia in different time periods.

The emission rate for the animal unit (AU) or living unit (LU) (which was calculated for every $500 \mathrm{~kg}$ bird living weight) ranged between 1.51 g $\mathrm{NH}_{3} /$ AU.h to $1.28 \mathrm{~g} \mathrm{NH}_{3} /$ AU.h. The importance of these emission modes was referred to its ability in comparisons between the different animals or the different types of stoking systems and densities. Variations 
in weights of animal grown in the same house area or even the same house but for a different weight categories could be controlled this modes.

\section{CONCLUSION}

Aerial ammonia emission rates vary according to different parameters such as temperature, relative humidity and air velocity furthermore, this emission may take different modes. So, there should be a feasible method installed with the house to measure/estimate indoor aerial ammonia concentration and outdoor ammonia from the house to surrounding environment. This reflects the urgent need to quantify ammonia NH3 and dust inside poultry houses to obtain a real vision of ammonia emission both inside and outside poultry houses.

\section{REFERENCES}

Aarnink, A. J. A., D. Swierstra, A. J. van den Berg and L. Speelman. 1997. Effect of types of slatted floor and degree of fouling of solid floor on ammonia emission rates from fattening piggeries. J. of Agric. Eng. Res.66 (2): 93-102.

Abdelbary, K. M.; M. H. Hatem; N. E. Gohar and A. E. Ghaly. 2004. Engineering and environmental studies on ammonia emitted from poultry houses. Conf. of Environ. \& Sustainable Dev., $44^{\text {th }}$ Ann. Sci. Week Activities, The Supreme Council of Sci., Al Baath Univ., Syria.

Alchalabi, D. A.; H. H. Person and A. Rhan. 1996. Use of $\mathrm{CO}_{2}$ and $\mathrm{NH}_{3}$ levels as minimum ventilation rate for poultry houses in winter. AMA. 27 (2): 71 - 74.

Bailey, J. A. ; P. Amyotte and F. I. Khan. 2010. Agricultural application of life cycle iNdeX (LInX) for effective decision making. J. of Cleaner Prod. 18: 1703-1713.

Bartali, E. and F. Wheaton. 1999. Handbook of Agricultural Engineering. Volume II. Animal Production \& Aquaculutral Engineering. ASAE. 2950 Niles Roads, St. Joseph, Michigan 49085-9659. USA. 
Buiter, J.J., and S.J. Hoff. 1998. Ammonia distribution in a pitventilated confinement building: One-half scale model study. Transactions of the ASAE. 41 (6): 1817 - 1827.

Carr, L. E., F. W. Wheaton, and L. W. Donglass. 1990. Empirical models to determine ammonia concentrations from broiler chicken litter. Trans., ASABE. 33 (4): 1337 - 1342.

Curtis, S. E. 1983. Environmental Management in Animal Agriculture. The Iowa State University Press., Ames, Iowa 50010.

Dugba, P. N., R. H. Zhang, T. R. Rumesy, T. G. Ellis. 1999. Computer simulation of a two-stage anaerobic sequencing batch reactors systems for animal wastewater treatment. Trans., ASABE. 42 (2): $471-477$.

Hellickson, M. A., and J. N. Walker. 1983. Ventilation of Agricultural Structures. ASABE .2950 Niles Roads, St. Joseph, Michigan 49085-9659. USA.

Hinz, T., and S. Linke. 1998(a). A comprehensive experimental study of aerial pollutants in and emissions from livestock buildings, Part 1: Methods. J. of Agric. Eng. Res. 70 (1): 111 - 118.

Hinz, T., and S. Linke. 1998(b). A comprehensive experimental study of aerial pollutants in and emissions from livestock buildings, Part 2: Results. J. of Agric. Eng. Res. 70 (1): 119 - 129.

Hobbs, P. J., T. H. Misselbrook, T. R. Cumby. 1999. Production and emission of odours and gases from ageing pig waste. J. of Agric. Eng. Res. 72 (3): 291 - 298.

http://agriculture.de/acms1/conf6/ws4ammon.htm? \&xdocopen=2\&xdoc= $\underline{0,0,0,0}$ 13/1/2001.

Ibrahim, M. H. 1998. A study on ammonia control in a poultry environment. Misr J. of Agric. Eng.15 (3):523-533.

Lo'pez, M. C.; A.J.A. Aarnink ; Y. Zhao; S. Calvet and A. G. Torres 2010. Airborne particulate matter from livestock production 
systems: A review of an air pollution problem. Environ. Pollution. 158: $1-17$.

Monteny, G. J. 2001. Quantify ammonia emissions from buildings, stores and land application.

Monteny, G. J.; D. D. Schulte; A. Elzing and E. J. J. Lamarker. 1996. Predicting modelling of ammonia emissions from cubicle dairy cow houses. Internal Conference on Air Pollution from Agric. Operations. MidWest Plan Service. P.215-220.Westin Crown Center, Kansas City, Missouri, USA.

Phillips, V.R.; M. R. Holden; R. W. Sneath; J. L. Short; R. P. White; J. Hartung; J. Seedorf; M. Schroder; K. H. Linkert; S. Pedersen; H. Takai; J. O. Johnsen; P. W. G. Groot Koerkamp; G. H. Uenk; R. Scholtens ;J. H. M. Metz C. M. Wathes. 1998. The development of robust methods for measuring concentrations and emission rates of gaseous and particulate air pollutants in livestock buildings. J. of Agric. Eng. Res. 70 (1): 11 -24.

Rose, C. C. and N. E. Davis. 1989. Selecting and using ammonia sensors. Poultry-Misset. 5 (5): 30 - 31.

Roumeliotis, T.S.; B.J. Dixon and B.J. Van Heyst. 2010(a). Characterization of gaseous pollutant and particulate matter emission rates from a commercial broiler operation part I: Observed trends in emissions. Atm. Environ. 44: 3770-3777.

Roumeliotis, T.S.; B.J. Dixon and B.J. Van Heyst. 2010(b). Characterization of gaseous pollutant and particulate matter emission rates from a commercial broiler operation part II: Correlated emission rates. Atm. Environ. 44:3778-3786.

Verdoes, N.; J. A. M. Voermans and C. E. P. Van Brakel. 1996. New housing systems for pigs: Dutch policy, ammonia emission and costs. Int. Conf. on Air Pollution from Agric. Operations. MidWest Plan Service. P.103-109.Westin Crown Center, Kansas City, Missouri, USA. 
Wheeler, E. F.; R. W. J. Weiss and E. Weidenboerner. 1999. Evaluation of instrumentation for the measurement of aerial ammonia in poultry houses. ASABE Paper No. 99-3188. An ASAE/CSAE Ann. Int. Meeting, Toronto, Canada.

Wynne, J.C.1995.Options for managing odor. Report. The Swine Odor Task Force. North Carolina Agricultural Research Service. North Carolina, USA.

Xin, H., I. L. Berry and G. T. Tabler. 1996. Minimum ventilation requirement and associated energy cost for aerial ammonia control in broiler houses. Trans., ASABE. 39 (2): 645 - 648.

Xue, S. K. and S. Chen. 1999. Surface oxidation for reducing ammonia and hydrogen sulfide emission from dairy manure storage. Trans., ASABE. 42 (5): 1401 - 1408.

Yang, Y., J. C. Lorimor and H. Xin. 2000. Nitrogen losses from laying hen manure in commercial high-rise layer facilities. Trans., ASABE. 43 (6): 1771 - 1780.

Zhang, R. H, D. L. Day, L. L. Christianson, and W. P. Jepson. 1994. A computer model for predicting ammonia release rates from swine manure pits. J. of Agric. Eng. Res. 58 (4): 223 - 229.

Zhang, R. H.; P. N. Dugba and D. S. Bundy. 1997. Laboratory study of surface aeration of anaerobic lagoons for odor control of swine manure. Trans., ASAE. 40 (1): 185 - 190.

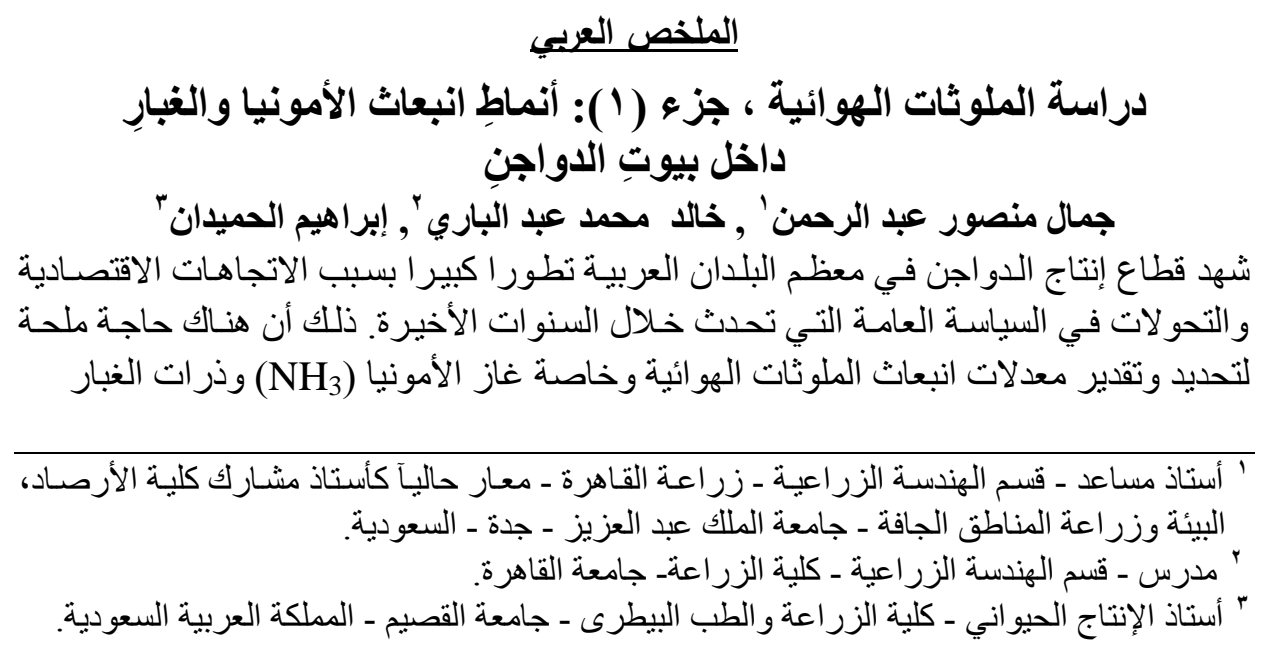




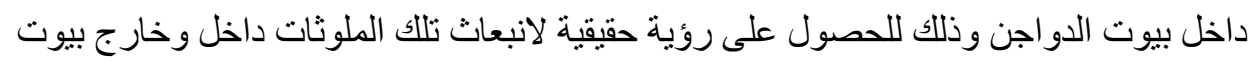

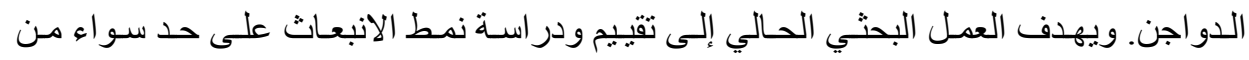

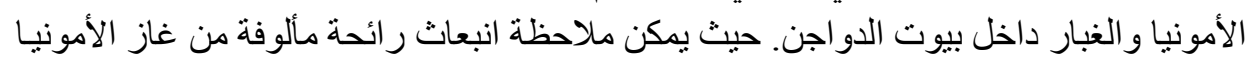

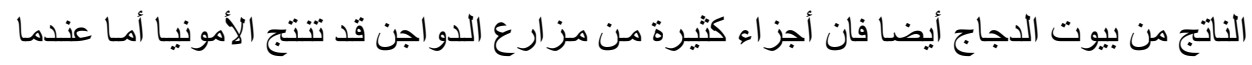

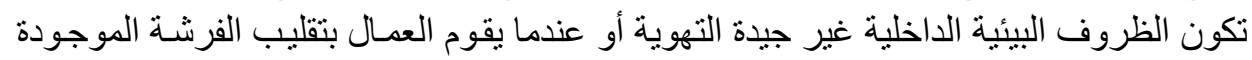

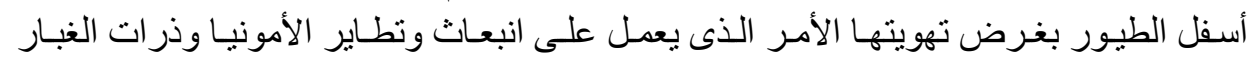

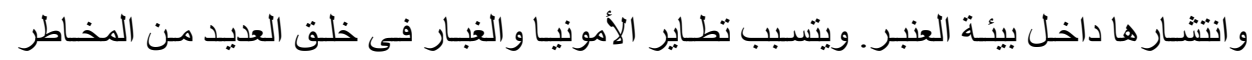

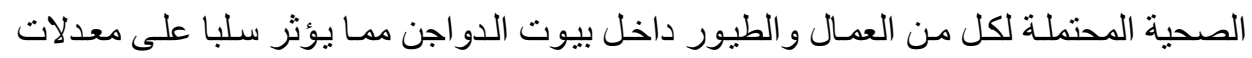

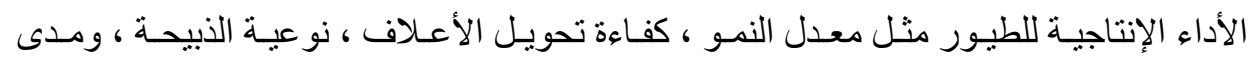

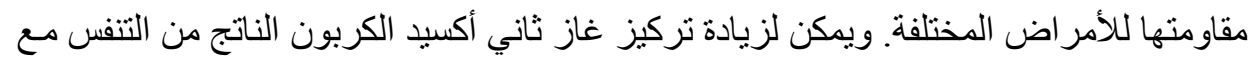

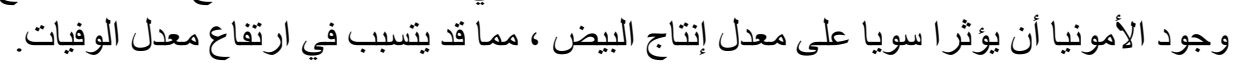

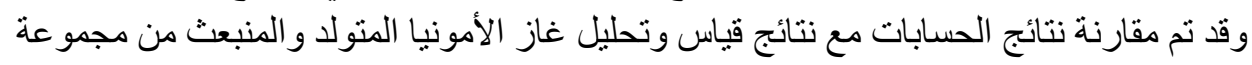

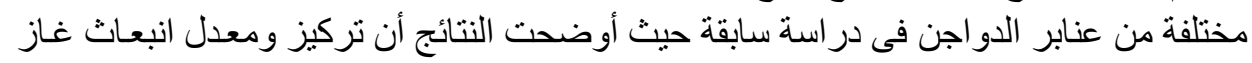

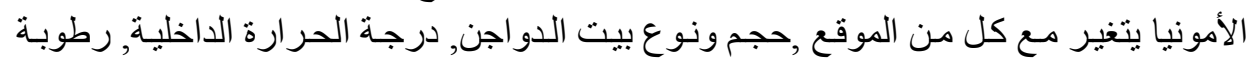

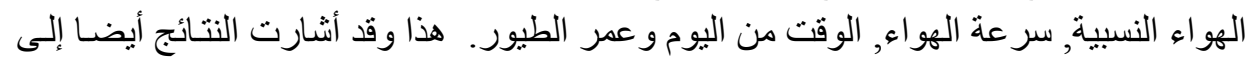

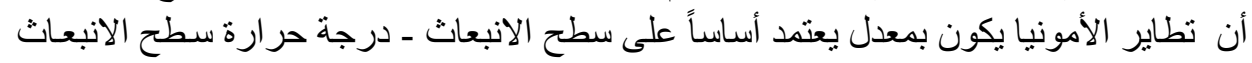

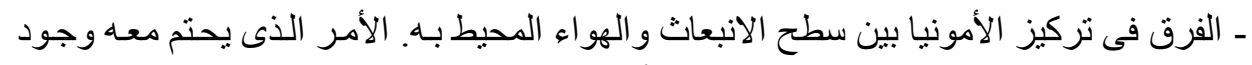

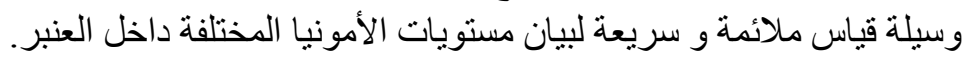
الكلمات الدالة: الأمونيا- غبار ـ انبعاث - بيئة - معدل نهوية_ نموذج - بيوت الدو اجن. 